OPEN ACCESS

Edited by:

Pablo Gregorini,

Lincoln University, New Zealand

Reviewed by:

Karl Kunert,

University of Pretoria, South Africa

Sheila Barry,

University of California,

Oakland, United States

${ }^{*}$ Correspondence:

Andrea K. Clemensen

Andrea.Clemensen@usda.gov

Specialty section:

This article was submitted to Agroecology and Ecosystem Services, a section of the journal

Frontiers in Sustainable Food Systems

Received: 31 March 2020

Accepted: 23 October 2020

Published: 19 November 2020

Citation:

Clemensen AK, Provenza FD,

Hendrickson JR and Grusak MA (2020) Ecological Implications of Plant

Secondary Metabolites -

Phytochemical Diversity Can Enhance

Agricultural Sustainability.

Front. Sustain. Food Syst. 4:547826.

doi: 10.3389/fsufs.2020.547826

\section{Ecological Implications of Plant Secondary Metabolites - Phytochemical Diversity Can Enhance Agricultural Sustainability}

\author{
Andrea K. Clemensen ${ }^{1 *}$, Frederick D. Provenza ${ }^{2}$, John R. Hendrickson ${ }^{1}$ and \\ Michael A. Grusak ${ }^{3}$ \\ ${ }^{1}$ United States Department of Agriculture, Agricultural Research Service, Northern Great Plains Research Laboratory, \\ Mandan, ND, United States, ${ }^{2}$ Department of Wildland Resources, Utah State University, Logan, UT, United States, \\ ${ }^{3}$ United States Department of Agriculture, Agricultural Research Service, Edward T. Schafer Agricultural Research Center, \\ Fargo, ND, United States
}

Conventional agriculture production, although proficient in feeding an expanding human population, is having negative environmental impacts that are diminishing the sustainability of natural resources. Producers and consumers are increasingly interested in understanding how land management practices can enhance agricultural sustainability and improve human health. This perspective article offers a new approach to enhancing agricultural sustainability by growing crops and forages with diverse plant secondary metabolites (PSMs). Plants produce tens of thousands of PSMs to mediate interactions with soil, other plants, and animals. Plants use these metabolites to communicate with organisms in their environment, both above and belowground, and to modify the rhizosphere and influence chemical, physical, and biological attributes of soil. In pastures and rangelands, animal health benefits and production increases when animals ingest forages with different PSMs, which has implications for enhancing the biochemical richness of meat and dairy products for human consumption. A deeper understanding of PSMs, and their functional roles in agroecology, may help producers better manage their lands, reduce inputs, and minimize negative environmental impacts.

Keywords: plant secondary metabolites, sustainable agriculture, foraging animals, agroecological resiliency, ecosystem health

\section{INTRODUCTION}

The industrialization of conventional agriculture has enhanced the proficiency of food production to support an increasing global population. Conventional crop and forage (hay or silage) production uses synthetic pesticides, herbicides, and fertilizers while conventional livestock production uses vaccines, antibiotics, medicated feeds, and growth hormones. The industrialization of conventional agriculture is the large-scale specialization of animals, crops, and forages for mass production (National Research Council, 2010). However, that has created a range of negative environmental impacts that are reducing the sustainability of agroecosystems. Conventional agriculture contributes to global greenhouse gas emissions, loss of plant biodiversity and soil organic matter, and degradation of natural resources, natural water bodies, and public health 
(Bauer and Black, 1981; Nixon, 1995; Doran and Safley, 1997; Vitousek et al., 1997; National Research Council, 2010). The National Research Council (2010) compiled a list of strategies to reduce the environmental impacts of conventional agriculture including crop rotation, cover crops, reduced and/or no-tillage, integrated pest management, precision farming, diversification of farm enterprises, genetically modified crops, and agricultural conservation management practices. We offer an additional strategy to reduce the negative environmental impacts of conventional agriculture, that being, to utilize crops and forages with diverse PSMs. Using biodiverse crops and forages with different biochemistries can reduce input requirements such as pesticides and fertilizers, and reduce the need for medication and parasiticides in animal production, thus reducing negative impacts from these inputs on the environment.

Besides producing the primary compounds necessary for growth, plants produce a diverse assortment of PSMs. Research over the last several decades has illuminated the ecological significance of PSMs in defense (herbivores, fungi, bacteria, viruses, plants), attraction and stimulation (pollination, seed dispersal, symbiosis, nutrient sequestration), and protection (UV-light, evaporation, temperature extremes, drought) of plants (Hartmann, 1996; Chomel et al., 2016). These activities are accomplished through three major classes of PSMs: (1) terpenes, (2) flavonoids, phenolic and polyphenolic compounds, and (3) nitrogen-containing (i.e., alkaloids) and sulfur-containing (e.g., glucosinolates) compounds (Crozier et al., 2001).

To support our view that phytochemical diversity can enhance agricultural sustainability we begin by discussing the ecological importance of PSMs with specific examples, illustrating their role in agroecological resiliency, then we examine the value of PSMs for foraging animals. Finally, we consider how increased understanding of the various roles of PSMs in ecological systems may enhance our ability to manage agricultural lands more sustainability by reducing input requirements for both plants and animals. This view, which is new in land management, integrates plant biochemical diversity to improve agroecological resiliency and can enhance agricultural sustainability.

\section{BENEFITS OF PLANT SECONDARY METABOLITES IN SOIL}

Soil health or quality is defined as the ability of soil to sustain the life of plants and animals below and above ground while also supporting ecosystem health including air and water (Doran, 1994; Doran et al., 1996; Doran and Safley, 1997; Johnson et al., 1997; Karlen et al., 1997). Soil physical, chemical, and biological properties are interdependent. Physical structure influences biological activity, which influences chemical composition and the soil microbiome. Physical properties encompass structure, texture, porosity, and bulk density, whereas chemical properties include cation-exchange capacity, $\mathrm{pH}$, salinity, macro- and micronutrients (Schoenholtz et al., 2000). Agricultural practices that diminish plant biodiversity also reduce plant biochemical diversity and degrade soil biological diversity (National Research Council, 2010; Ristok et al., 2019).
Through diverse PSMs, plants modify their environment in various ways including interactions that affect the soil microbiome in the rhizosphere, soil nutrient cycling, allelopathy, and defenses against herbivores (van Dam and Bouwmeester, 2016; Coskun et al., 2017). Plants exude certain PSMs to enhance their ability to acquire nutrients from the soil. For example, alfalfa (Medicago sativa) seeds and roots release flavonoids that promote the growth of Sinorhizobium meliloti, a N-fixing gramnegative bacterium (Hartwig et al., 1991). Under conditions of iron deficiency, some graminaceous plants (i.e., wheat, oats, barley, rye) exude mugineic acid which solubilizes iron, making it more readily available to plants (Ma and Nomoto, 1996).

Plant secondary metabolites influence soil decomposition. Tannins and terpenes affect cycling of $\mathrm{C}$ and $\mathrm{N}$ by increasing $\mathrm{N}$ immobilization in the soil (Bradley et al., 2000; Smolander et al., 2012). Pasture forages such as sainfoin (Onobrychis viciifolia Scop.), which contains condensed tannins, can inhibit soil $\mathrm{N}$ mineralization (Clemensen et al., 2020) and reduce $\mathrm{N}$ loss in pastures where $\mathrm{N}$ mineralization is relatively rapid. Tannins and terpenes in plant litter slow rates of nutrient cycling by supplying more recalcitrant $\mathrm{C}$ substrate, binding with proteins, and/or acting as toxins to soil microbes (Smolander et al., 2012), all of which inhibit $\mathrm{N}$ mineralization. Laboratory studies with forest soils show terpenes decrease nitrification potential and at low $\mathrm{pH}$ they precipitate proteins (Adamczyk et al., 2013). While terpenes can be toxic to soil microorganisms, tannins form complexes with proteins and enzymes (Hättenschwiler and Vitousek, 2000; Kraus et al., 2003; Adamczyk et al., 2011, 2019), and also form complexes with fungal compounds (i.e., Dichomitus squalens) (Adamczyk et al., 2019), which slows microbial decomposition processes that affect $\mathrm{C}$ and $\mathrm{N}$ cycling (Northup et al., 1995; Hättenschwiler et al., 2019). The incredibly diverse polyphenol class of PSMs is reflected in their varied influences on the soil microbial community. For instance, greater soil respiration occurs with additions of the monomeric phenol methyl gallate compared with polyphenol epigallocatechin gallate and polyphenol oenothein B (Schmidt et al., 2013). To our knowledge, research evaluating the influence of specific PSMs on soil dynamics is largely limited to forest systems, while little is known regarding these dynamics in pasture and/or cropping systems.

Root exudates contain various PSMs that can attract, deter, or kill belowground insect herbivores, nematodes, and microbes, and inhibit competing plants. Plants that exude PSMs from their roots can more easily defend themselves from below-ground injury. Plants also use these exudates to establish their spatial presence among other plant species and to communicate with other plants and animals above and belowground. For instance, in response to the root-eating larvae, Diabrotica virgifera, teosinte, the ancestor of wild maize and other European lines of maize, produces the volatile sesquiterpene (E)- $\beta$-caryophyllene, which attracts entomopathogenic nematodes (Rasmann et al., 2005), indirectly defending the plant against the larvae. Interestingly, newer varieties of maize in North America do not release this volatile compound as a defense mechanism (Degen et al., 2004). Alfalfa contains various saponins (triterpenes), most of which are oleananes and steroids (Kregiel et al., 2017). 
Oleoresin, which has antifungal properties against Pestalotiopsis microspora (Chen et al., 2018), is made up of triterpenes, some of which are oleanane saponins (Liang et al., 1988). The release of flavonoids from alfalfa seeds and roots slows growth of parasitic species of Pythium spp. (Hartwig et al., 1991). In forest soil, terpenes, common in conifer trees, increase bacterial growth but decrease fungal growth (Adamczyk et al., 2013), yet studies exploring these dynamics in other agricultural systems is limited.

Water availability is a growing concern in agriculture. Plants respond to water stress in various ways, including increasing or decreasing primary and secondary metabolites. For example, red poppy (Papaver somniferum) increases concentrations of alkaloids to enhance drought tolerance (Sarker and Oba, 2018; Yang et al., 2018). Depending on the species, saponin levels decrease as some species go into reproductive phase or increase as other species age (Pecetti et al., 2006). Saponin concentrations are greater in roots than in stems, leaves, and flowers in a variety of species (e.g., Dioscorea pseudojaponica, Polygala tenuifolia, Bupleurum chinense, Achyranthus bidentate, Gypsophilia paniculate) (Szakiel et al., 2011), including alfalfa (Tava et al., 1993). Saponins contain both a hydrophilic and lipophilic end; thus, they can form spherical structures called micelle with negatively charged surfaces that typically do not form aggregates. However, if water solutions contain $\mathrm{Ca}+$ and $\mathrm{Mg}+$ ("hard" water), the micelle can form cluster aggregates, increasing water holding capacity of soil. Saponins can also reduce surface tension in aqueous solutions (Böttger et al., 2012), and by acting as surfactants they can potentially increase soil water holding capacity, thus enhancing the ability of saponincontaining plants to withstand drought.

Arbuscular mycorrhiza fungi are estimated to have formed stable relationships with roughly $80 \%$ of plant families (Smith and Read, 1997). They play major roles in soil health including protecting plants from biotic and abiotic stresses and supporting plants by releasing glomalin. Glomalin enhances the stability and water retention of soil, subsequently increasing water and nutrient uptake by plants, thus reducing fertilizer requirements (Gianinazzi et al., 2010). Additionally, arbuscular mycorrhizal fungi increase specific PSMs in plants, from 6\% (methyl chavicol, a phenylpropanoid) to $697 \%$ ( $\alpha$-pinene, a terpene), in both field and greenhouse experiments (Kapoor et al., 2002, 2004; Gianinazzi et al., 2010), enhancing the ability of plants to adapt to different environmental circumstances.

Knowledge of PSMs can be used in land management strategies to further enhance agroecological resiliency and agricultural sustainability. For instance, tannin-containing plants such as sainfoin or birdsfoot trefoil may inhibit soil $\mathrm{N}$ mineralization, thus reducing $\mathrm{N}$ loss, while saponin-containing plants such as alfalfa may enhance soil water holding capacity.

\section{BENEFITS OF PLANT SECONDARY METABOLITES TO PLANTS}

Plant secondary metabolites offer a broad range of benefits to plants, from attracting pollinators and seed dispersers (Knudsen et al., 1993; Pichersky and Gershenzon, 2002; Bruce and Pickett,
2011; Pierik et al., 2014) to defending plants from pathogens and diseases by helping plants recover from injury (Savatin et al., 2014). Flavonoids protect plants from ultraviolet radiation (Agati and Tattini, 2010), while glycyrrhizin (a triterpene saponin) may also boost UV protection, as its production in roots increases with greater UV-B light exposure in Glycyrrhiza uralensis (Afreen et al., 2005). Other terpenes, the carotenoid group of tetraterpenes, more commonly known as the yellow, orange, and red pigments, likewise aid in photoprotection while also extending the range of light used in photosynthesis, regulating the effects of extreme temperatures, and protecting photosynthetic tissues from photooxidation (Strzalka et al., 2003). Phenolic compounds such as tannins may increase due to stress from UV light, heat, and/or drought (Yang et al., 2018). For example, red maple (Acer rubrum L.) doubles the amount of tannins in response to drought and warming (Tharayil et al., 2011), while red oak (Quercus rubra L.) varies both the concentration and molecular composition of tannins to better adapt to climatic stresses (Top et al., 2017).

Plant secondary metabolites are diverse in structure and function, and their production is influenced by interactions above and belowground that involve genetic, ontogenetic, morphogenetic, and biotic and abiotic factors (Verma and Shukla, 2015; Shamloo et al., 2017; Kessler and Kalske, 2018; Yang et al., 2018). Their production reflects the unique and dynamic environments plants encounter. They may increase when plants are stressed or grow in suboptimal conditions (Kamstrup et al., 2000; Yang et al., 2018). Saponins in some species peak during temperature extremes, such as hot summer and cold winter months, and decrease in spring and fall with milder temperatures, while saponins in other species may peak during the milder seasons of spring and fall (Szakiel et al., 2011). Saponin concentrations in individual soapbark trees (Quillaja saponaria) differ even under similar soil conditions, altitude, and age of trees suggesting genetics play a role in the production of PSMs (Kamstrup et al., 2000).

Chemical responses within plants are genetically derived and environmentally induced, and thus can differ between and within species, and among different tissues in a plant (Macel et al., 2010; Verma and Shukla, 2015). Depending on the plant species, and specific secondary metabolite, some PSMs are produced and then stored in tissues (e.g., tannins) while others are produced de novo in response to environmental perturbations (e.g., various monoterpenes and alkaloids). These metabolites are concentrated in particular plant cells or tissues, restricted to particular developmental stages of growth, and transferred "long distances" within plants via the xylem and/or phloem or "short distances" via translocation between cells (Hartmann, 1996).

Plants also release various volatile compounds to interact with their environment (Pichersky and Gershenzon, 2002; Laothawornkitkul et al., 2009; Baldwin, 2010). Most of these compounds are terpenoids that may be emitted differently depending on circadian rhythms. Volatile compounds can attract or deter pollinators, and they also play vital roles in direct and indirect defenses for plants (Turlings et al., 1995; Kessler and Baldwin, 2001; Pichersky and Gershenzon, 2002). For instance, when the tobacco plant (Nicotina attenuata Torr. ex 
Wats.) is attacked by the tobacco hornworm (Manduca sexta L.), a nicotine-tolerant folivore, the plant suppresses its typical folivore-induced increase in nicotine production (Baldwin, 1988), and instead emits an assortment of volatile organic compounds $[(\mathrm{E})$ - $\alpha$-bergamotene] that attract the generalist predator Geocoris pallens as a defense against Manduca (Kessler and Baldwin, 2001; Halitschke et al., 2007; Zhou et al., 2017). Plants naturally produce insecticides that may negate the need for synthetic insecticide applications if crop and forage varieties are selected and managed to increase production of these PSMs. For example, the alkaloid nicotine deters herbivores so effectively (Steppuhn et al., 2004) it has been used commercially as an insecticide (Soloway, 1976). Other insecticidal PSMs include pyrethrins (Xu et al., 2018), and the triterpene azadirachtin, found in citrus (limonoids), which is non-toxic to plants and animals yet is a strong insect deterrent (Aerts and Mordue Luntz, 1997). Natural biochemicals such as pyrethroids have been used to create synthetic insecticides due to their effectiveness at deterring insects, their evanescence in the environment, and their minimal impact to mammals.

Rarely does one secondary metabolite enable plants to cope with environmental challenges. Rather, plants rely on combinations of different metabolites (Gershenzon and Dudareva, 2007). Plant volatiles are typically emitted in blended "bouquets" (Baldwin, 2010) that have layered functions of attractants or deterrents. Badenes-Perez et al. (2014) found a positive correlation between the feeding deterrents glucosinolate (a sulfur-containing compound) and saponins (triterpenes) for insects consuming Brassicaceae species.

The production of PSMs is a crucial way that plants interact within their social and biophysical environments. In our view, strategic management and utilization of plant phytochemical diversity may improve agricultural sustainability and resiliency while reducing input requirements. As we discuss next, at appropriate doses PSMs add health benefits for consumption by herbivores and humans (Provenza et al., 2019).

\section{IMPACT OF PLANT SECONDARY METABOLITES ON FORAGING ANIMALS}

Some PSMs are well known for their poisonous potential to animals, and herbivores respond by reducing their intake of plants containing PSMs as a function of the concentration of the metabolites in plants (Provenza et al., 2002, 2003). As Paracelsus (1493-1541) wrote, "All substances are poisons; there is none which is not a poison. The right dose differentiates a poison from a remedy."

Plant secondary metabolites, namely alkaloids, can be toxic to ruminants (Stidham et al., 1982; Rhodes et al., 1991; Aldrich et al., 1993; Thompson et al., 2001). However, by offering animals either supplements (Mantz et al., 2008; Bernard et al., 2013; Jensen et al., 2014), or diverse forages containing different PSMs (Lyman et al., 2008, 2011, 2012; Owens et al., 2012a,b), biochemical complementarities can reduce the negative effects of alkaloids in plants like endophyte-infected tall fescue (Schedonorus arundinaceus) and terpenes in plants like sagebrush (Artemisia tridentata), either by binding or through other mechanisms (Freeland et al., 1985; Charlton et al., 2000; Seefeldt, 2005; Mote et al., 2008; Catanese et al., 2014; Clemensen et al., 2017).

Phenolic compounds have antioxidative and anticarcinogenic benefits that also aid digestion (Waghorn et al., 1994; Waghorn, 2008). Condensed tannins reduce internal parasites and nematodes in ruminants and, due to their proteinbinding characteristics, also enhance the absorption of amino acids in the small intestine, analogous to by-pass proteins popular in ruminant nutrition (Barry and McNabb, 1999; Villalba et al., 2013). Like tannins, saponins can precipitate proteins (Livingston et al., 1979), while lowering cholesterol in animals (Aazami et al., 2013). Saponins may improve growth and feed efficiency, reduce protozoa in the rumen, and increase efficiency of rumen-microbial protein synthesis (Francis et al., 2002).

The emphasis on planting monocultures, combined with the influence of PSMs on reducing intake of any one forage, is why these metabolites have historically been bred out of plants used for crops and forages (Wink, 1988; Jacobsen, 1998; Provenza et al., 2007). Foraging animals eat more and perform better when offered a variety of forages with different kinds and amounts of PSMs (Provenza, 1996; Provenza et al., 2007, 2009), which at appropriate doses offer numerous health benefits to foraging animals (Engel, 2002; Cheeke et al., 2006; Provenza and Villalba, 2010; Meuret and Provenza, 2015). Historically, researchers and producers have focused on the three to five species which contribute the most to intake of energy and protein for livestock, but animals will eat an additional 50-75 species in a meal. These 50-75 other plant species are equally, if not more important for the health of livestock and humans through the meat and dairy products we derive from them (Provenza et al., 2019).

\section{PLANT SECONDARY METABOLITES, HERBIVORES, AND HUMAN HEALTH}

In addition to improving the health of foraging animals, ingesting various PSMs enhances the phytochemical and biochemical richness, flavor, and quality of cheese, milk, and meat for human consumption (Vasta et al., 2008; Vasta and Luciano, 2011; Maughan et al., 2014; Provenza et al., 2019). Our health is thus linked with the diets of livestock through the chemical characteristics of the plant species they eat. Through their antiinflammatory, immunomodulatory, antioxidant, anti-bacterial, and anti-parasitic properties, phytochemicals in plants protect livestock and humans against diseases and pathogens (Provenza, 2018). The benefits of eating meat to humans accrue as livestock convert rich arrays of phytochemicals into biochemicals that are incorporated into their meat and fat, which in turn become healthy biochemicals in human bodies, similar to the benefits attained by eating phytochemically rich herbs, spices, vegetables, and fruits (Provenza et al., 2019). Those compounds may confer the same benefits to us as to livestock, dampening oxidative stress and inflammation linked with cancer, cardiovascular disease, and metabolic syndrome. 
Historically, plants were the source of medicine for all animals, including humans. Today, various drugs (antibiotics, pain killers, fever reducers, etc.) are derived from plants that produce these chemicals naturally. Several reviews describe the many health promoting properties of PSMs to animals, including humans (Verpoorte, 1998; Craig, 1999; Bourgaud et al., 2001; Maganha et al., 2010; Kabera et al., 2014). The opportunity is to reconsider the fundamentally important roles these compounds played in health before the advent of modern medicine (Provenza, 2018), while integrating plants with diverse PSMs back into our crops and forages.

\section{PLANT DIVERSITY IN AGRICULTURAL SYSTEMS}

Over the past 50 years, we have simultaneously come to better understand the roles of PSMs in protecting plants against herbivores, pathogens, and competition, while reducing their concentrations in crop and pasture plants to maximize yields. In their stead, cultivation and synthetic chemicals have been used to protect plants grown in monocultures. With good intentions to feed an exponentially growing human population, the simplification of agricultural systems has produced various negative impacts too numerous to overlook (Foley, 2005; Hendrickson et al., 2008; Hendrickson and Colazo, 2019), resulting in a need for change.

Increasing plant diversity in agricultural systems offers ecosystem benefits from the soil, to plants and animals, to the atmosphere, enhancing agroecological sustainability. Belowground, PSMs defend against root-eating larvae while also influencing nutrient cycling as carbonaceous metabolites such as tannins and terpenes slow mineralization in the soil, potentially increasing soil microbial biomass, thus increasing carbon sequestration potential in agriculture soil. Aboveground, PSMs aid plants and act as insecticides when defoliation pressure develops. Diverse plant species with differing PSMs enhance balanced eating habits while also offering health benefits to herbivores and humans (Provenza et al., 2007). Further, methane emissions are reduced when cattle graze forages containing tannins (Pinares-PatiñO et al., 2003; Boadi et al., 2004; Woodward et al., 2004; Beauchemin et al., 2007; Jayanegara et al., 2009). Thus, planting forages containing different PSMs may reduce greenhouse gasses by influencing rumen fermentation and soil mineralization (Goel and Makkar, 2012; Provenza et al., 2019).

We have emphasized growth of crops and livestock, at the expense of phytochemical richness, through the varieties we have selected and the management practices we have used, including applications of water and fertilizer to enhance growth, and pesticides to prevent herbivory by insects. Alternatively, stressing plants by reducing inputs of fertilizers, insecticides, and water can increase production of PSMs, which typically increase with various environmental stressors (Shamloo et al., 2017; Yang et al., 2018; Roberts and Mattoo, 2019). However, research is needed to further explore how stress via reduced inputs may influence the biosynthesis of PSMs in crops and forages. A deeper understanding of PSMs, and their functional roles in agroecology, may help producers better manage their lands, reduce inputs, and minimize negative environmental impacts.

We have discussed qualitative aspects of PSMs in enhancing agricultural sustainability. We have not mentioned the quantification of these metabolites. Quantifying PSMs in any system is challenging, as each species differs in production between root and shoot tissues with varying circumstances. Thus, it is difficult to quantify how much of any specific PSM enters a system (i.e., Kraus et al., 2003). Recent results suggest that the concentration of tannins in cattle feces is proportional to the concentration of tannins in the forage consumed (Stewart et al., 2019). Models must consider concentrations of PSMs in plant tissues, as well as PSMs exuded from roots, and residual PSMs in decomposing plant matter. Further, the analytical procedures for extracting and quantifying PSMs is labor intensive and typically requires substantial quantities of laboratory chemicals. Thus, a need for developing more efficient methods of analysis is essential. Additional research opportunities exist in evaluating which crops and forages may contain optimal PSMs to reach land management objectives.

It is ironic that we have selected against PSMs in crop and pasture plants that we are now intent on genetically engineering back into plants (Provenza et al., 2007). Enhancing plant biodiversity and associated phytochemical diversity offers a logical progression to improve agricultural resilience while providing ecosystem services that also benefit the health of herbivores and humans.

\section{AUTHOR'S NOTE}

The USDA prohibits discrimination in all its programs and activities on the basis of race, color, national origin, age, disability, and where applicable, sex, marital status, family status, parental status, religion, sexual orientation, genetic information, political beliefs, reprisal, or because all or part of an individual's income is derived from any public assistance program. (Not all prohibited bases apply to all programs). The USDA is an equal opportunity provider and employer. Mention of commercial products and organizations in this manuscript is solely to provide specific information. It does not constitute endorsement by USDA-ARS over other products and organizations not mentioned.

\section{AUTHOR CONTRIBUTIONS}

All authors listed have made a substantial, direct and intellectual contribution to the work, and approved it for publication.

\section{FUNDING}

This work was funded through US Department of Agriculture project 3064-21660-004-00D to AC and JH and project 306021650-001-00D to MG. This research was a contribution from the Long-Term Agroecosystem Research (LTAR) network. LTAR is supported by the United States Department of Agriculture. 


\section{REFERENCES}

Aazami, M. H., Tahmasbi, A. M., Ghaffari, M. H., Naserian, A. A., Valizadeh, R., and Ghaffari, A. H. (2013). Effects of saponins on rumen fermentation, nutrients digestibility, performance, and plasma metabolites in sheep and goat kids. Ann. Rev. Res. Bio. 3, 596-607. Available online at: http://www. sciencedomain.org/review-history/1576

Adamczyk, B., Adamczyk, S., Smolander, A., and Kitunen, V. (2011). Tannic acid and Norway spruce condensed tannins can precipitate various organic nitrogen compounds. Soil Biol. Biochem. 43, 628-637. doi: 10.1016/j.soilbio.2010.11.034

Adamczyk, B., Sietiö, O. M., Biasi, C., and Heinonsalo, J. (2019). Interaction between tannins and fungal necromass stabilizes fungal residues in boreal forest soils. New Phytol. 223, 16-21. doi: 10.1111/nph.15729

Adamczyk, S., Kiikkilä, O., Kitunen, V., and Smolander, A. (2013). Potential response of soil processes to diterpenes, triterpenes and tannins: nitrification, growth of microorganisms and precipitation of proteins. Appl. Soil Ecol. 67, 47-52. doi: 10.1016/j.apsoil.2013.02.009

Aerts, R. J., and Mordue Luntz, A. J. (1997). Feeding deterrence and toxicity of neem triterpenoids. J. Chem. Ecol. 23, 2117-2132. doi: 10.1023/B:JOEC.0000006433.14030.04

Afreen, F., Zobayed, S. M. A., and Kozai, T. (2005). Spectral quality and UV-B stress stimulate glycyrrhizin concentration of Glycyrrhiza uralensis in hydroponic and pot system. Plant Physiol. Biochem. 43, 1074-1081. doi: 10.1016/j.plaphy.2005.11.005

Agati, G., and Tattini, M. (2010). Multiple functional roles of flavonoids in photoprotection: letters. New Phytol. 186, 786-793. doi: $10.1111 /$ j.1469-8137.2010.03269.x

Aldrich, C. G., Rhodes, M. T., Miner, J. L., Kerley, M. S., and Paterson, J. A. (1993). The effects of endophyte-infected tall fescue consumption and use of a dopamine antagonist on intake, digestibility, body temperature, and blood constituents in sheep. J. Anim. Sci. 71, 158-163. doi: 10.2527/1993. $711158 \mathrm{x}$

Badenes-Perez, F. R., Gershenzon, J., and Heckel, D. G. (2014). Insect attraction versus plant defense: young leaves high in glucosinolates stimulate oviposition by a specialist herbivore despite poor larval survival due to high saponin content. PLoS ONE 9:e95766. doi: 10.1371/journal.pone.0095766

Baldwin, I. T. (1988). The alkaloidal responses of wild tobacco to real and simulated herbivory. Oecologia 77, 378-381. doi: 10.1007/BF00378046

Baldwin, I. T. (2010). Plant volatiles. Curr. Biol. 20, 392-397. doi: $10.1016 /$ j.cub.2010.02.052

Barry, T. N., and McNabb, W. C. (1999). The implications of condensed tannins on the nutritive value of temperate forages fed to ruminants. Br. J. Nutr. 81, 263-272. doi: 10.1017/S0007114599000501

Bauer, A., and Black, A. L. (1981). Soil carbon, nitrogen, and bulk density comparisons in two cropland tillage systems after 25 years and in virgin grassland. Soil Sci. Soc. Am. J. 45, 1166-1170. doi: 10.2136/sssaj1981.03615995004500060032x

Beauchemin, K. A., McGinn, S. M., Martinez, T. F., and McAllister, T. A. (2007). Use of condensed tannin extract from quebracho trees to reduce methane emissions from cattle. J. Anim. Sci. 85:1990. doi: 10.2527/jas.2006-686

Bernard, M., Maughan, B., and Villalba, J. J. (2013). Preference for tannincontaining supplements by sheep consuming endophyte-infected tall fescue hay. J. Anim. Sci. 91, 3445-3456. doi: 10.2527/jas.2012-5406

Boadi, D., Benchaar, C., Chiquette, J., and Mass,é, D. (2004). Mitigation strategies to reduce enteric methane emissions from dairy cows: update review. Can. J. Anim. Sci. 84, 319-335. doi: 10.4141/A03-109

Böttger, S., Hofmann, K., and Melzig, M. F. (2012). Saponins can perturb biologic membranes and reduce the surface tension of aqueous solutions: a correlation? Bioorg. Med. Chem. 20, 2822-2828. doi: 10.1016/j.bmc.2012.03.032

Bourgaud, F., Gravot, A., Milesi, S., and Gontier, E. (2001). Production of plant secondary metabolites: a historical perspective. Plant Sci. 161, 839-851. doi: 10.1016/S0168-9452(01)00490-3

Bradley, R. L., Titus, B. D., and Preston, C. P. (2000). Changes to mineral $\mathrm{N}$ cycling and microbial communities in black spruce humus after additions of $\left(\mathrm{NH}_{4}\right)_{2} \mathrm{SO}_{4}$ and condensed tannins extracted from Kalmia angustifolia and balsam fir. Soil Biol. Biochem. 32, 1227-1240. doi: 10.1016/S0038-0717(00)00039-0
Bruce, T. J. A., and Pickett, J. A. (2011). Perception of plant volatile blends by herbivorous insects - finding the right mix. Phytochemistry 72, 1605-1611. doi: 10.1016/j.phytochem.2011.04.011

Catanese, F., Distel, R. A., and Villalba, J. J. (2014). Effects of supplementing endophyte-infected tall fescue with sainfoin and polyethylene glycol on the physiology and ingestive behavior of sheep. J. Anim. Sci. 92, 744-757. doi: $10.2527 /$ jas.2013-6713

Charlton, A. J., Davis, A. L., Jones, D. P., Lewis, J. R., Davies, A. P., Haslam, E., et al. (2000). The self-association of the black tea polyphenol theaflavin and its complexation with caffeine. J. Chem. Soc. Perkin Trans. 2, 317-322. doi: $10.1039 / \mathrm{a} 906380 \mathrm{c}$

Cheeke, P. R., Piacente, S., and Oleszek, W. (2006). Anti-inflammatory and anti-arthritic effects of yucca schidigera: a review. J. Inflam. 3:6. doi: 10.1186/1476-9255-3-6

Chen, T., Lu, J., Kang, B., Lin, M., Ding, L., Zhang, L., et al. (2018). Antifungal activity and action mechanism of ginger oleoresin against Pestalotiopsis microspora isolated from Chinese olive fruits. Front. Microbiol. 9:2583. doi: $10.3389 /$ fmicb. 2018.02583

Chomel, M., Guittonny-Larchevêque, M., Fernandez, C., Gallet, C., DesRochers, A., Paré, D., et al. (2016). Plant secondary metabolites: a key driver of litter decomposition and soil nutrient cycling. J. Ecol. 104, 1527-1541. doi: 10.1111/1365-2745.12644

Clemensen, A. K., Rottinghaus, G. E., Lee, S. T., Provenza, F. D., and Villalba, J. J. (2017). How planting configuration influences plant secondary metabolites and total $\mathrm{N}$ in tall fescue (Festuca arundinacea Schreb.), Alfalfa (Medicago sativa L.) and birdsfoot trefoil (Lotus corniculatus L.): implications for grazing management. Grass Forage Sci. 73, 94-100. doi: 10.1111/gfs. 12298

Clemensen, A. K., Villalba, J. J., Rottinghaus, G. E., Lee, S. T., Provenza, F. D., and Reeve, J. R. (2020). Do plant secondary metabolite-containing forages influence soil processes in pasture systems? Agron. J. 112, 3744-3757. doi: 10.1002/agj2.20361

Coskun, D., Britto, D. T., Shi, W., and Kronzucker, H. J. (2017). How plant root exudates shape the nitrogen cycle. Trends Plant Sci. 22, 661-673. doi: $10.1016 /$ j.tplants.2017.05.004

Craig, W. J. (1999). Health-promoting properties of common herbs. Am. J. Clin. Nutr. 70, 491s-499s. doi: 10.1093/ajen/70.3.491s

Crozier, A., Clifford, M. N., and Ashihara, H. (2001). Plant Secondary Metabolites: Occurrence, Structure and Role in the Human Diet. Chichester: John Wiley \& Sons, Incorporated. Available online at: http://ebookcentral.proquest.com/lib/ usu/detail.action?docID $=351346$

Degen, T., Dillmann, C., Marion-Poll, F., and Turlings, T. C. J. (2004). High genetic variability of herbivore-induced volatile emission within a broad range of maize inbred lines. Plant Physiol. 135, 1928-1938. doi: 10.1104/pp.104. 039891

Doran, J. W., and Safley, M. (1997). "Defining and assessing soil health and sustainable productivity," in Biological Indicators of Soil Health. (Wallingford, NY : CAB International), 1-28. Available online at: http://dist.lib.usu.edu/ login?url=http://search.ebscohost.com/login.aspx?direct=true\&db=agr\&AN= IND20626773\&site=ehost-live

Doran, J. W., Sarrantonio, M., and Liebig, M. A. (1996). "Soil health and sustainability," in Advances in Agronomy, Vol. 56, ed D. L. Sparks (San Diego, CA: Academic Press), 1-54

Doran, J. W., and Soil Science Society of America (1994). Defining Soil Quality for a Sustainable Environment: Proceedings of a Symposium Sponsored by Divisions S-3, S-6, and S-2 of the Soil Science Society of America, Division A-5 of the American Society of Agronomy, and the North Central Region Committee on Soil Organic Matter (NCR-59) in Minneapolis, MN, 4-5 November 1992. SSSA Special Publication, no. 35 (Madison, WI: SSSA, American Society of Agronomy).

Engel, C. (2002). Wild Health: How Animals Keep Themselves Well and What We Can Learn from Them. Weidenfeld \& Nicolson. Available online at: https:// books.google.com/books?id=sweBPwAACAAJ

Foley, J. A. (2005). Global consequences of land use. Science 309, 570-574. doi: $10.1126 /$ science. 1111772

Francis, G., Kerem, Z., Makkar, H. P. S., and Becker, K. (2002). The biological action of saponins in animal systems: a review. Br. J. Nutr. 88:587. doi: 10.1079/BJN2002725 
Freeland, W. J., Calcott, P. H., and Anderson, L. R. (1985). Tannins and saponin: interaction in herbivore diets. Biochem. Syst. Ecol. 13, 189-193. doi: 10.1016/0305-1978(85)90078-X

Gershenzon, J., and Dudareva, N. (2007). The function of terpene natural products in the natural world. Nat. Chem. Biol. 3, 408-414. doi: 10.1038/nchembio.2007.5

Gianinazzi, S., Gollotte, A., Binet, M. N., van Tuinen, D., Redecker, D., and Wipf, D. (2010). Agroecology: the key role of arbuscular mycorrhizas in ecosystem services. Mycorrhiza 20, 519-530. doi: 10.1007/s00572-010-0333-3

Goel, G., and Makkar, H. P. S. (2012). Methane mitigation from ruminants using tannins and saponins. Trop. Anim. Health Prod. 44, 729-739. doi: 10.1007/s11250-011-9966-2

Halitschke, R., Stenberg, J. A., Kessler, D., Kessler, A., and Baldwin, I. T. (2007). Shared signals 'alarm calls' from plants increase apparency to herbivores and their enemies in nature. Ecol. Lett. 11, 24-34. doi: 10.1111/j.1461-0248.2007.01123.x

Hartmann, T. (1996). Diversity and variability of plant secondary metabolism: a mechanistic view. Entomol. Exp. Appl. 80, 177-188. doi: 10.1111/j.1570-7458.1996.tb00914.x

Hartwig, U. A., Joseph, C. M., and Phillips, D. A. (1991). Flavonoids released naturally from alfalfa seeds enhance growth rate of Rhizobium meliloti. Plant Physiol. 95, 797-803. doi: 10.1104/pp.95.3.797

Hättenschwiler, S., Sun, T., and Coq, S. (2019). The chitin connection of polyphenols and its ecosystem consequences. New Phytol. 223, 5-7. doi: $10.1111 / \mathrm{nph} .15840$

Hättenschwiler, S., and Vitousek, P. M. (2000). The role of polyphenols in terrestrial ecosystem nutrient cycling. Trends Ecol. Evol. 15, 238-243. doi: $10.1016 /$ S0169-5347(00)01861-9

Hendrickson, J., and Colazo, J. C. (2019). Chapter 6 - Using crop diversity and conservation cropping to develop more sustainable arable cropping systems," in Agroecosystem Diversity, eds G. Lemaire, P. C. F. Carvalho, S. Kronberg, and S. Recous (Cambridge, MA: Academic Press), 93-108.

Hendrickson, J., Sassenrath, G. F., Archer, D., Hanson, J., and Halloran, J. (2008). Interactions in integrated US agricultural systems: the past, present and future. Renew. Agric. Food Syst. 23, 314-324. doi: 10.1017/S1742170507001998

Jacobsen, S. E. (1998). Developmental stability of quinoa under European conditions. Indus. Crops Prod. 7, 169-174. doi: 10.1016/S0926-6690(97)00045-9

Jayanegara, A., Togtokhbayar, N., Makkar, H. P. S., and Becker, K. (2009). Tannins determined by various methods as predictors of methane production reduction potential of plants by an in vitro rumen fermentation system. Anim. Feed Scie. Technol. 150, 230-237. doi: 10.1016/j.anifeedsci.2008.10.011

Jensen, T. F., Provenza, F. D., and Villalba, J. J. (2014). Influence of drinking water with quebracho tannin on intake of endophyte-infected tall fescue by cattle. Anim. Feed Sci. Technol. 188, 13-16. doi: 10.1016/j.anifeedsci.2013.11.005

Johnson, D. L., Ambrose, S. H., Bassett, T. J., Bowen, M. L., Crummey, D. E., Isaacson, J. S., et al. (1997). Meanings of environmental terms. J. Environ. Qual. 26:581. doi: 10.2134 /jeq1997.00472425002600030002x

Kabera, J. N., Semana, E., Mussa, A. R., and He, X. (2014). Plant secondary metabolites: biosynthesis, classification, function and pharmacological properties. J. Pharm. Pharmacol. 2, 377-392.

Kamstrup, S., Martin, R. S., Doberti, A., Grande, H., and Dalsgaard, K. (2000). Preparation and characterisation of Quillaja saponin with less heterogeneity than Quil-A. Vaccine 18, 2244-2249. doi: 10.1016/S0264-410X(99)00560-5

Kapoor, R., Giri, B., and Mukerji, K. G. (2002). Mycorrhization of coriander (Coriandrum sativum $\mathrm{L}$ ) to enhance the concentration and quality of essential oil. J. Sci. Food Agric. 82, 339-342. doi: 10.1002/jsfa.1039

Kapoor, R., Giri, B., and Mukerji, K. G. (2004). Improved growth and essential oil yield and quality in Foeniculum vulgare mill on mycorrhizal inoculation supplemented with P-fertilizer. Bioresour. Technol. 93, 307-311. doi: 10.1016/j.biortech.2003.10.028

Karlen, D. L., Mausbach, M. J., Doran, J. W., Cline, R. G., Harris, R. F., and Schuman, G. E. (1997). Soil quality: a concept, definition, and framework for evaluation (a guest editorial). Soil Sci. Soc. Am. J. 61, 4-10. doi: 10.2136/sssaj1997.03615995006100010001x

Kessler, A., and Baldwin, I. T. (2001). Defensive function of herbivoreinduced plant volatile emissions in nature. Science 291, 2141-2144. doi: $10.1126 /$ science.291.5511.2141
Kessler, A., and Kalske, A. (2018). Plant secondary metabolite diversity and species interactions. Annu. Rev. Ecol. Evol. Syst. 49, 115-138. doi: 10.1146/annurev-ecolsys-110617-062406

Knudsen, J. T., Tollsten, L., and Bergström, L. G. (1993). Floral scents-a checklist of volatile compounds isolated by head-space techniques. Phytochemistry 33, 253-280. doi: 10.1016/0031-9422(93)85502-I

Kraus, T. E. C., Dahlgren, R. A., and Zasoski, R. J. (2003). Tannins in nutrient dynamics of forest ecosystems - a review. Plant Soil 256, 41-66. doi: 10.1023/A:1026206511084

Kregiel, D., Berlowska, J., Witonska, I., Antolak, H., Proestos, C., Babic, M., et al. (2017). "Saponin-based, biological-active surfactants from plants," in Application and Characterization of Surfactants, ed R. Najjar (Rijeka: InTech).

Laothawornkitkul, J., Taylor, J. E., Paul, N. D., and Hewitt, C. N. (2009). Biogenic volatile organic compounds in the earth system. New Phytol. 183, 27-51. doi: $10.1111 / j .1469-8137.2009 .02859 . x$

Liang, G. Y., Gray, A. L., and Waterman, P. G. (1988). Tirucallane and oleanane triterpenes from the resin of Aucoumea klaineana. Phytochemistry 27, 2283-2286. doi: 10.1016/0031-9422(88)80143-2

Livingston, A. L., Knuckles, B. E., Edwards, R. H., Fremery, D. D., Miller, R. E., and Kohler, G. O. (1979). Distribution of saponin in alfalfa protein recovery systems. J. Agric. Food Chem. 27, 362-365. doi: 10.1021/jf60222a051

Lyman, T. D., Provenza, F. D., and Villalba, J. J. (2008). Sheep foraging behavior in response to interactions among alkaloids, tannins and saponins. J. Sci. Food Agric. 88, 824-831. doi: 10.1002/jsfa.3158

Lyman, T. D., Provenza, F. D., Villalba, J. J., and Wiedmeier, R. D. (2011). Cattle preferences differ when endophyte-infected tall fescue, birdsfoot trefoil, and alfalfa are grazed in different sequences. J. Anim. Sci. 89, 1131-1137. doi: $10.2527 /$ jas.2009-2741

Lyman, T. D., Provenza, F. D., Villalba, J. J., and Wiedmeier, R. D. (2012). Phytochemical complementarities among endophyte-infected tall fescue, reed canarygrass, birdsfoot trefoil and alfalfa affect cattle foraging. Animal 6, 676-682. doi: 10.1017/S1751731111001996

Ma, J. F., and Nomoto, K. (1996). Effective regulation of iron acquisition in graminaceous plants. The role of mugineic acids as phytosiderophores. Phys. Plant. 97, 609-617. doi: 10.1111/j.1399-3054.1996.tb00522.x

Macel, M., van Dam, N. M., and Keurentjes, J. J. B. (2010). Metabolomics: the chemistry between ecology and genetics: invited technical review. Mol. Ecol. Resour. 10, 583-593. doi: 10.1111/j.1755-0998.2010.02854.x

Maganha, E. G., da Costa Halmenschlager, R., Rosa, R. M., Henriques, J. A. P., de Paula Ramos, A. L. L., and Saffi, J. (2010). Pharmacological evidences for the extracts and secondary metabolites from plants of the genus Hibiscus. Food Chem. 118, 1-10. doi: 10.1016/j.foodchem.2009.04.005

Mantz, G. K., Villalba, J. J., and Provenza, F. D. (2008). Supplemental polyethylene glycol affects intake of and preference for sericea lespedeza by cattle. J. Anim. Sci. 87, 761-769. doi: 10.2527/jas.2007-0706

Maughan, B., Provenza, F. D., Tansawat, R., Maughan, C., Martini, S., Ward, R., et al. (2014). Importance of grass-legume choices on cattle grazing behavior, performance and meat characteristics. J. Anim. Sci. 92:2309. doi: $10.2527 /$ jas.2013-7297

Meuret, M., and Provenza, F. (2015). How French shepherds create meal sequences to stimulate intake and optimise use of forage diversity on rangeland. Anim. Prod. Sci. 55:309. doi: 10.1071/AN14415

Mote, T., Villalba, J. J., and Provenza, F. D. (2008). Foraging sequence influences the ability of lambs to consume foods containing tannins and terpenes. Appl. Anim. Behav. Sci. 113, 57-68. doi: 10.1016/j.applanim.2007.10.003

National Research Council (2010). Toward Sustainable Agricultural Systems in the 21st Century. Washington, DC: National Academies Press.

Nixon, S. W. (1995). Coastal marine eutrophication: a definition, social causes, and future concerns. Ophelia 41, 199-219. doi: 10.1080/00785236.1995.10422044

Northup, R. R., Dahlgren, R. A., and Yu, Z. (1995). Intraspecific variation of conifer phenolic concentration on a marine terrace soil acidity gradient; a new interpretation. Plant Soil 171, 255-262. doi: 10.1007/BF00 010279

Owens, J., Provenza, F. D., Wiedmeier, R. D., and Villalba, J. J. (2012a). Supplementing endophyte-infected tall fescue or reed canarygrass with alfalfa or birdsfoot trefoil increases forage intake and digestibility by sheep. J. Sci. Food Agric. 92, 987-992. doi: 10.1002/jsfa.4681 
Owens, J., Provenza, F. D., Wiedmeier, R. D., and Villalba, J. J. (2012b). Influence of saponins and tannins on intake and nutrient digestion of alkaloid-containing foods. J. Sci. Food Agric. 92, 2373-2378. doi: 10.1002/jsfa.5643

Pecetti, L., Tava, A., Romani, M., De Benedetto, M. G., and Corsi, P. (2006). Variety and environment effects on the dynamics of saponins in lucerne (Medicago sativa L.). Eur. J. Agron. 25, 187-192. doi: 10.1016/j.eja.2006.04.013

Pichersky, E., and Gershenzon, J. (2002). The formation and function of plant volatiles: perfumes for pollinator attraction and defense. Curr. Opin. Plant Biol. 5, 237-243. doi: 10.1016/S1369-5266(02)00251-0

Pierik, R., Ballaré, C. L., and Dicke, M. (2014). Ecology of plant volatiles: taking a plant community perspective: ecology of plant volatiles. Plant Cell Environ. 37, 1845-1853. doi: $10.1111 /$ pce. 12330

Pinares-PatiñO., C. S., Ulyatt, M. J., Waghorn, G. C., Lassey, K. R., Barry, T. N., et al. (2003). Methane emission by alpaca and sheep fed on lucerne hay or grazed on pastures of perennial ryegrass/white clover or birdsfoot trefoil. J. Agric. Sci. 140, 215-226. doi: 10.1017/S002185960300306X

Provenza, F. D. (1996). Acquired aversions as the basis for varied diets of ruminants foraging on rangelands. J. Anim. Sci. 74, 2010-2020. doi: $10.2527 / 1996.7482010 \mathrm{x}$

Provenza, F. D. (2018). Nourishment: What Animals Can Teach Us About Rediscovering Our Nutritional Wisdom. White River Junction, VT: Chelsea Green Publishing.

Provenza, F. D., Kronberg, S. L., and Gregorini, P. (2019). Is grassfed meat and dairy better for human and environmental health? Front. Nutr. 6:26. doi: 10.3389/fnut.2019.00026

Provenza, F. D., and Villalba, J. J. (2010). The role of natural plant products in modulating the immune system: an adaptable approach for combating disease in grazing animals. Small Rumin. Res. 89, 131-139. doi: 10.1016/j.smallrumres.2009.12.035

Provenza, F. D., Villalba, J. J., and Bryant, J. P. (2002). "Foraging by herbivores: linking the biochemical diversity of plants with herbivore culture and landscape diversity," in Landscape Ecology and Resource Management: Linking Theory With Practice, eds J. A. Bissonette and I. Storch (New York, NY: Island Press), 387-421.

Provenza, F. D., Villalba, J. J., Dziba, L. E., Atwood, S. B., and Banner, R. E. (2003). Linking herbivore experience, varied diets, and plant biochemical diversity. Small Rumin. Res. 49, 257-274. doi: 10.1016/S0921-4488(03)00143-3

Provenza, F. D., Villalba, J. J., Haskell, J., MacAdam, J. W., Griggs, T. C., and Wiedmeier, R. D. (2007). The value to herbivores of plant physical and chemical diversity in time and space. Crop Sci. 47:382. doi: 10.2135/cropsci2006. 02.0083

Provenza, F. D., Villalba, J. J., Wiedmeier, R. W., Lyman, T., Owens, J., Lisonbee, L., et al. (2009). Value of plant diversity for diet mixing and sequencing in herbivores. Rangelands 31, 45-49. doi: 10.2111/1551-501X-31.1.45

Rasmann, S., Köllner, T. G., Degenhardt, J., Hiltpold, I., Toepfer, S., Kuhlmann, U., et al. (2005). Recruitment of entomopathogenic nematodes by insect-damaged maize roots. Nature 434, 732-737. doi: 10.1038/nature03451

Rhodes, M. T., Paterson, J. A., Kerley, M. S., Garner, H. E., and Laughlin, M. H. (1991). Reduced blood flow to peripheral and core body tissues in sheep and cattle induced by endophyte-infected tall fescue. J. Anim. Sci. 69, 2033-2043. doi: $10.2527 / 1991.6952033 \mathrm{x}$

Ristok, C., Poeschl, Y., Dudenhöffer, J.-H., Ebeling, A., Eisenhauer, N., Vergara, F., et al. (2019). Plant species richness elicits changes in the metabolome of grassland species via soil biotic legacy. J. Ecol. 107, 2240-2254. doi: 10.1111/1365-2745.13185

Roberts, D. P., and Mattoo, A. K. (2019). Sustainable crop production systems and human nutrition. Front. Sustain. Food Syst. 3:72. doi: 10.3389/fsufs.2019.00072

Sarker, U., and Oba, S. (2018). Drought stress enhances nutritional and bioactive compounds, phenolic acids and antioxidant capacity of amaranthus leafy vegetable. BMC Plant Biol. 18:258. doi: 10.1186/s12870-018-1484-1

Savatin, D. V., Gramegna, G., Modesti, V., and Cervone, F. (2014). Wounding in the plant tissue: the defense of a dangerous passage. Front. Plant Sci. 5:470. doi: 10.3389/fpls.2014.00470

Schmidt, M. A., Kreinberg, A. J., Gonzalez, J. M., Halvorson, J. J., French, E., Bollmann, A., et al. (2013). Soil microbial communities respond differently to three chemically defined polyphenols. Plant Physiol. Biochem. 72, 190-197. doi: 10.1016/j.plaphy.2013.03.003

Schoenholtz, S. H., Van Miegroet, H., and Burger, J. A. (2000). A review of chemical and physical properties as indicators of forest soil quality: challenges and opportunities. Forest Ecol. Manage. 138, 335-356. doi: 10.1016/S0378-1127(00)00423-0

Seefeldt, S. S. (2005). Consequences of selecting Ramboulliet ewes for mountain big sagebrush (Artemisia tridentata ssp. vaseyana) dietary preference. Rangeland Ecol. Manage. 58, 380-384. doi: 10.2111/1551-5028(2005)058[0380:COSREF]2. $0 . \mathrm{CO} ; 2$

Shamloo, M., Babawale, E. A., Furtado, A., Henry, R. J., Eck, P. K., and Jones, P. J. H. (2017). Effects of genotype and temperature on accumulation of plant secondary metabolites in Canadian and Australian wheat grown under controlled environments. Sci. Rep. 7:9133. doi: 10.1038/s41598-017-09681-5

Smith, S. E., and Read, D. J. (1997). Mycorrhizal Symbiosis, 2nd Edn. San Diego, CA: Academic Press.

Smolander, A., Kanerva, S., Adamczyk, B., and Kitunen, V. (2012). Nitrogen transformations in boreal forest soils-does composition of plant secondary compounds give any explanations? Plant Soil 350, 1-26. doi: 10.1007/s11104-011-0895-7

Soloway, S. B. (1976). Naturally occurring insecticides. Environ. Health Perspect. 14:109. doi: 10.1289/ehp.7614109

Steppuhn, A., Gase, K., Krock, B., Halitschke, R., and Baldwin, I. T. (2004). Nicotine's defensive function in nature. PLoS Biol. 2:e217. doi: 10.1371/journal.pbio.0020217

Stewart, E. K., Beauchemin, K. A., Dai, X., MacAdam, J. W., Christensen, R. G., and Villalba, J. J. (2019). Effect of tannin-containing hays on enteric methane emissions and nitrogen partitioning in beef cattle. J. Anim. Sci. 97, 3286-3299. doi: $10.1093 /$ jas/skz206

Stidham, W. D., Piper, E. L., Featherstone, H. E., Brown, C. J., and Danielsm, L. B. (1982). Toxic fescue linked to reduced milk output in ewes. Arkansas Farm Res. 31:9.

Strzalka, K., Kostecka-Gugala, A., and Latowski, D. (2003). Carotenoids and environmental stress in plants: significance of carotenoid-mediated modulation of membrane physical properties. Russ. J. Plant Physiol. 50, 168-173. doi 10.1023/A:1022960828050

Szakiel, A., Paczkowski, C., and Henry, M. (2011). Influence of environmental abiotic factors on the content of saponins in plants. Phytochem. Rev. 10, 471-491. doi: 10.1007/s11101-010-9177-x

Tava, A., Oleszek, W., Jurzysta, M., Berardo, N., and Odoardi, M. (1993). Alfalfa saponins and sapogenins: isolation and quantification in two different cultivars. Phytochem. Anal. 4, 269-274. doi: 10.1002/pca.2800040605

Tharayil, N., Suseela, V., Triebwasser, D. J., Preston, C. M., Gerard, P. D., and Dukes, J. S. (2011). Changes in the structural composition and reactivity of acer rubrum leaf litter tannins exposed to warming and altered precipitation: climatic stress-induced tannins are more reactive. New Phytol. 191, 132-145. doi: 10.1111/j.1469-8137.2011.03667.x

Thompson, F. N., Stuedemann, J. A., and Hill, N. S. (2001). Anti-quality factors associated with alkaloids in eastern temperate pasture. J. Range Manage. 54:474. doi: $10.2307 / 4003119$

Top, S. M., Preston, C. M., Dukes, J. S., and Tharayil, N. (2017). Climate influences the content and chemical composition of foliar tannins in green and senesced tissues of Quercus rubra. Front. Plant Sci. 8:423. doi: 10.3389/fpls.2017.00423

Turlings, T. C., Loughrin, J. H., McCall, P. J., Rose, U. S., Lewis, W. J., and Tumlinson, J. H. (1995). How caterpillar-damaged plants protect themselves by attracting parasitic wasps. Proc. Natl. Acad. Sci. 92, 4169-4174. doi: $10.1073 /$ pnas.92.10.4169

van Dam, N. M., and Bouwmeester, H. J. (2016). Metabolomics in the rhizosphere: tapping into belowground chemical communication. Trends Plant Sci. 21, 256-265. doi: 10.1016/j.tplants.2016.01.008

Vasta, V., and Luciano, G. (2011). The effects of dietary consumption of plants secondary compounds on small ruminants' products quality. Small Rumin. Res. 101, 150-59. doi: 10.1016/j.smallrumres.2011.09.035

Vasta, V., Nudda, A., Cannas, A., Lanza, M., and Priolo, A. (2008). Alternative feed resources and their effects on the quality of meat and milk from small ruminants. Anim. Feed Sci. Technol. 147, 223-46. doi: 10.1016/j.anifeedsci.2007.09.020

Verma, N., and Shukla, S. (2015). Impact of various factors responsible for fluctuation in plant secondary metabolites. J. Appl. Res. Med. Arom. Plants 2, 105-113. doi: 10.1016/j.jarmap.2015.09.002

Verpoorte, R. (1998). Exploration of nature's chemodiversity: the role of secondary metabolites as leads in drug development. Drug Discov. Today 3, 232-238. doi: 10.1016/S1359-6446(97)01167-7 
Villalba, J. J., Miller, J., Hall, J. O., Clemensen, A. K., Stott, R., Snyder, D., et al. (2013). Preference for tanniferous (Onobrychis viciifolia) and nontanniferous (Astragalus cicer) forage plants by sheep in response to challenge infection with Haemonchus contortus. Small Rumin. Res. 112, 199-207. doi: 10.1016/j.smallrumres.2012.11.033

Vitousek, P. M., Aber, J. D., Howarth, R. W., Likens, G. E., Matson, P. A., Schindler, D. W., et al. (1997). Technical report: human alteration of the global nitrogen cycle: sources and consequences. Ecol. Appl. 7:737. doi: 10.2307/2269431

Waghorn, G. (2008). Beneficial and detrimental effects of dietary condensed tannins for sustainable sheep and goat production-progress and challenges. Anim. Feed Sci. Technol. 147, 116-139. doi: 10.1016/j.anifeedsci.2007. 09.013

Waghorn, G. C., Shelton, I. D., McNabb, W. C., and McCutcheon, S. N. (1994). Effects of Condensed tannins in Lotus pedunculatus on its nutritive value for sheep. 2. Nitrogenous aspects. J. Agric. Sci. 123, 109-19. doi: $10.1017 /$ S0021859600067836

Wink, M. (1988). Plant breeding: importance of plant secondary metabolites for protection against pathogens and herbivores. Theor. Appl. Genet. 75, 225-233. doi: 10.1007/BF00303957

Woodward, S. L., Waghorn, G. C., and Laboyrie, P. G. (2004). “Condensed tannins in birdsfoot trefoil (Lotus corniculatus) reduce methane emissions from dairy cows," in Proceedings of the New Zealand Society of Animal Production, Vol. 64 (Hamilton: New Zealand Society of Animal Production), 160-64.
Xu, H., Lybrand, D., Bennewitz, S., Tissier, A., Last, R. L., and Pichersky, E. (2018). Production of trans-chrysanthemic acid, the monoterpene acid moiety of natural pyrethrin insecticides, in tomato fruit. Metab. Eng. 47, 271-278. doi: 10.1016/j.ymben.2018.04.004

Yang, L., Wen, K.-S., Ruan, X., Zhao, Y.-X., Wei, F., and Wang, Q. (2018). Response of plant secondary metabolites to environmental factors. Molecules 23:762. doi: 10.3390/molecules23040762

Zhou, W., Kügler, A., McGale, E., Haverkamp, A., Knaden, M., Guo, H., et al. (2017). Tissue-specific emission of (E)- $\alpha$-bergamotene helps resolve the dilemma when pollinators are also herbivores. Curr. Biol. 27, 1336-1341. doi: 10.1016/j.cub.2017.03.017

Conflict of Interest: The authors declare that the research was conducted in the absence of any commercial or financial relationships that could be construed as a potential conflict of interest.

Copyright (c) 2020 Clemensen, Provenza, Hendrickson and Grusak. This is an openaccess article distributed under the terms of the Creative Commons Attribution License (CC BY). The use, distribution or reproduction in other forums is permitted, provided the original author(s) and the copyright owner(s) are credited and that the original publication in this journal is cited, in accordance with accepted academic practice. No use, distribution or reproduction is permitted which does not comply with these terms. 